\title{
Antoni Mironowicz
}

Białystok

\section{Likwidacja unii kościelnej na soborze połockim (1839 r.)}

Po III rozbiorze Rzeczpospolitej nastąpiła likwidacja niezależnej struktury cerkiewnej na terenie dawnych ziem polskich. W stosunku do ośrodków prawosławnych na ziemiach włączonych do Rosji Świątobliwy Synod Kościoła prawosławnego podjął energiczne działania. Władze rosyjskie narzuciły ośrodkom prawosławnym ustrój synodalno-konsystorski, likwidując jego odrębność prawną i organizacyjną. Od współzarządzania Cerkwią został odsunięty element świecki, w tym bractwa cerkiewne. Kościół prawosławny na dawnych ziemiach Rzeczypospolitej zatracił swoją kulturową specyfikę i organizacyjną niezależność, stając się częścią Rosyjskiego Kościoła Prawosławnego. Na dawnych terenach Wielkiego Księstwa Litewskiego odsunięto od godności cerkiewnych miejscowych duchownych, a na ich miejsce sprowadzono duchowieństwo rosyjskie, które ujednolicało życie parafialne i klasztorne według praw kanonicznych i zwyczajów obowiązujących w Cerkwi rosyjskiej. Parafie znajdujące się na ziemiach polskich, litewskich i białoruskich podporządkowano jurysdykcji biskupa mińskiego i poddano procesowi całkowitej unifikacji z Rosyjskim Kościołem Prawosławnym¹. Pozostałe dawne ziemie wschodnie Rzeczypospolitej znalazły się w granicach Cesarstwa Austriackiego. Sytuacja prawna ludności prawosławnej w obu państwach była odmienna. Inna była też droga likwidacji unii w Cesarstwie Rosyjskim i Królestwie Polskim.

$$
* * *
$$

\footnotetext{
1 O dziejach Kościoła prawosławnego na ziemiach polskich do 1918 r. por.: A. Mironowicz, Kościót prawosławny na ziemiach dawnej Rzeczypospolitej (1596-1918), [w:] Prawostawie. Światto wiary i zdrój doświadczenia, pod red. K. Leśniewskiego i J. Leśniewskiej, Lublin 1999, s. 473-548; Kościót prawosławny w dawnej Rzeczypospolitej, Białystok 2001; Kościót prawosławny w państwie Piastów i Jagiellonów, Białystok 2003; Bractwa cerkiewne w Rzeczypospolitej, Białystok 2003; Kościót prawosławny na ziemiach polskich w XIX i XX wieku, Białystok 2005; Kościót prawosławny w Polsce, Białystok 2006.
} 
W wyników rozbiorów Rzeczypospolitej oraz zmian granic po pokoju w Tylży (1807) i Kongresie Wiedeńskim na terenie Imperium Rosyjskiego znalazło się pięć diecezji unickich: metropolitarna, połocka, włodzimierska, łucka i chełmska. Rosyjski Kościół Prawosławny i panujący w Rosji niechętnie odnosili się do unitów. Powszechnie uważano, że unici powinni wrócić do prawosławia. Latynizacja i polonizacja unitów stanowiła dodatkowy powód do podjęcia takich działań. Po raz pierwszy planową akcję nawracania unitów przeprowadzono na Wołyniu i Podolu w latach 1793-1794. Wyniku prowadzonej akcji misyjnej, kierowanej przez biskupa Wiktora Sadkowskiego, na prawosławie przeszło około 200 parafii unickich i około miliona wiernych ${ }^{2}$.

Po śmierci Katarzyny II akcja misyjna ustała. Car Paweł I, choć nie lubił unitów, to ich nie prześladował. Za jego rządów restytuowano, obok istniejącego arcybiskupstwa połockiego, biskupstwo łuckie i brzeskie. Kościół unicki liczył wówczas 1500 parafii, 80 klasztorów bazyliańskich i 1428000 wiernych ${ }^{3}$. Aleksander I również nie zwalczał unitów. Po przejściu części unitów na obrządek łaciński wydał nawet dekret zabraniający nawracania unitów. Ukazem z 1805 r. podzielił Kolegium Duchowne na dwa niezależne departamenty: łaciński i unicki. W każdym z nich zasiadali duchowni właściwego obrządku. Takie postanowienie miało zapobiec dominacji duchowieństwa rzymskokatolickiego nad unickim. Aleksander I zgodził się ponadto na ustanowienie unickiej diecezji litewskiej. W konsekwencji w granicach Cesarstwa Rosyjskiego znalazły się cztery diecezje unickie: litewska, połocka, łucka i brzeska. Piąta diecezja unicka - chełmska znalazła się w granicach Królestwa Polskiego.

Za panowania Aleksandra I (1800-1824) nastąpił dalszy wzrost znaczenia Rosji w Europie, zwłaszcza po odparciu najazdu wojsk Napoleona I na Moskwę w 1812 r. Car rosyjski był inicjatorem Świętego Przymierza, a Rosja uzyskała miano żandarma Europy. Jednym punktów kongresu wiedeńskiego było ustanowienie Królestwa Polskiego, któremu car Aleksander I nadał w 1815 r. konstytucję. Konstytucja w artykule 11 głosiła, że religia rzymskokatolicka ,,jest przedmiotem szczególnej opieki rządu, ale gwarantowała równocześnie pełne prawa innym wyznaniom, „które wszystkie bez wyłączenia obrządki swe całkowicie i publicznie pod pretekcyją rządu odbywać mogą"4. Taki zapis w konstytucji wynikał z faktu, że na terenie Królestwa Polskiego dominowali wyznawcy Kościoła rzymskokatolickiego $(83,5 \%)$ i greckokatolickiego (2,5\%). Ludność protestancka stanowiła 3,75\% ogółu mieszkańców Królestwa Polskiego, a wyznania

2 E. Likowski, Dzieje Kościoła Unickiego na Litwie i Rusi w XVIII i XIX wieku, cz. I, Warszawa 1906, s. 256; H. Dylagowa, Kościót unicki na ziemiach Rzeczypospolitej 1596-1918, „Przegląd Wschodni", t. II, z. 2 (6), 1992/1993, s. 277.

3 Ibidem, s. 277.

4 Z. A. Stankiewicz, Królestwo Polskie 1815-1830, [w:] Historia państwa i prawa Polski, t. III, Warszawa 1981, s. 411. 
mojżeszowego około 10\%. Społeczność prawosławna stanowiła niewielki odsetek społeczeństwa 5 .

Odmienną od Aleksandra I politykę wobec unitów prowadził Mikołaj I. Uważał on duchownych unickich narodowości białoruskiej lub ukraińskiej za osobowy powiązane z kulturą wschodnią, które należy pozyskać do prawosławia. Za jego rządów więcej uwagi władze państwowe i cerkiewne poświęcał pomocy ludności prawosławnej zamieszkującej zachodnie granice Imperium Rosyjskiego. Carat popierał ideologię państwa prawosławnego opartego na symbiozie: ,prawosławia, samowładztwa i narodowości rosyjskiej”. W odróżnieniu od poprzednika car Mikołaj I wspierał tendencje integrystyczne w Cerkwi prawosławnym ${ }^{6}$. W przypadku Kościoła unickiego dążono do oczyszczenia obrządku wschodniego z naleciałości łacińskich. Przywrócenie w cerkwiach unickich pełnej obrzędowości wschodniej miało być wstępem do bezkonfliktowego zjednoczenia z prawosławiem. „Nawracanie” unitów na prawosławie nie miało mieć akcji jednorazowej, ale było przygotowane na kilka lat. Główną rolę w tym procesie miał odegrać Józef Siemaszko, stojący wówczas w centrum spraw obrządku greckokatolickiego.

Józef Siemaszko urodził się 25 grudnia 1798 r. we wsi Pawłówka, powiatu lipowickiego. Ojciec jego, Timofiej Siemaszko, był duchownym unickim ${ }^{7}$. Początki swej edukacji Siemaszko zdobywał u prawosławnego diakona Boczkowskiego, a następnie w niemirowskim gimnazjum. W 1816 r. wstąpił do Głównego Seminarium w Wilnie, gdzie po czteroletniej nauce uzyskał tytuł doktora teologii. W 1820 r. został wyświęcony przez władykę unickiego Jakuba Martusiewicza na duchownego. $Z$ uwagi na jego duże zdolności organizacyjne i intelektualne Józefa Siemaszko wybrano na członka Konsystorza diecezji łuckiej. W 1822 r. został wybrany przewodniczącym tego Konsystorza i dziekanem łuckim. W tym samym r. wyznaczono go przedstawicielem unickiego departamentu w kolegium rzymskokatolickim w Petersburgu. Siemaszko rozpoczął starania na rzecz poprawy prawnego i materialnego położenia unitów w Cesarstwie Rosyjskim8.

5 Historia Polski w liczbach. Terytorium, ludność, Warszawa 1999, s. 63; J. K. Jańczak, Struktura ludności Królestwa Polskiego 1815-1830, „Przeszłość Demograficzna Polski”, 1984, t. XIV, s. 25-49; B. Kumor, Historia Kościoła, t. VII, Lublin 2002, s. 82.

6 S. W. Rimskij, Stosunki między Cerkwia prawostawna a państwem w Rosji w XIX wieku, [w:] Chrześcijaństwo $w$ dialogu kultur na ziemiach Rzeczypospolitej, pod red. St. Wilka, Lublin 2003, s. 402-411.

7 Dane o życiu Józefa Siemaszki zostały zaczerpnięte z opracowanych przez niego zapisów; por. I. Siemaszko, Zapiski mitropolita litowskogo izdannyja Impieratorskoju Akadiemijeju Nauk po zawieszczaniju awtora, t. I, Sankt-Pietierburg 1893. Biografia Józefa Siemaszki znajduje się w Podręcznej Encyklopedii Katolickiej, t. XXXV-XXXVI, Warszawa 1912.

8 A. Mironowicz, Kościót prawostawny na ziemiach dawnej Rzeczypospolitej (1596-1918), s. $537-538$. 
W Petersburgu pogłębiło się wyniesione z dzieciństwa przywiązanie Józefa Siemaszki do prawosławia. Oczarowała go architektura sakralna, malarstwo i śpiew. Doznania artystyczne nie przysłoniły mu różnic dogmatycznych i organizacyjnych obu Kościołów. Świadomość ich przezwyciężenia legła u postaw przyszłej działalności duchownego unickiego. Pomogło mu w tym poznanie w Petersburgu teologii prawosławnej i bogactwo wartości religijnej prawosławia. Kilkanaście lat później Siemaszko napisał: „(...) dawno przekonałem się do prawosławia Cerkwi wschodniej, a to dzięki czytaniu i szczegółowym poszukiwaniom, a jednocześnie należałem do Kościoła zachodniego"9. Podjęcie działalności w kierunku zjednoczenia unitów z Cerkwią prawosławną napotkało szereg przeciwności. Przeciwne zjednoczeniu było duchowieństwo rzymskokatolickie i znaczna część unickiego. Niekonsekwentną politykę w stosunku do unitów prowadziła hierarchia Rosyjskiego Kościoła Prawosławnego i administracja carska. Jedynie dzięki szczególnym zdolnościom organizacyjnym Józefa Siemaszki udało się zahamować latynizację obrządku unickiego i zainteresować planem zjednoczenia swych współwyznawców oraz wpływowych osób w Moskwie i Petersburgu. Działalność tę Siemaszko mógł podjąć po objęciu w Konsystorzu wszystkich spraw związanych z funkcjonowaniem Kościoła greckokatolickiego w Rosji. Będąc w Petersburgu, Siemaszko doprowadził w latach dwudziestych XIX wieku do powrotu z katolicyzmu 20 tysięcy unitów, do wydania edyktu przez cara Mikołaja w 1826 r. zakazującego budowy kościołów łacińskich wśród ludności unickiej i zakazu z 1827 r. wstępowania do klasztorów bazyliańskich nie unitów ${ }^{10}$.

W 1827 r. Józef Siemaszko opracował memoriał o stanie Kościoła greckokatolickiego w Rosji, w którym przeanalizował dzieje unii i przedłożył plan zjednoczenia unitów z Cerkwią prawosławną. Projekt zyskał poparcie cara Mikołaja I. W 1828 r. nastąpiły pierwsze istotne posunięcia oddzielające unitów od katolików, m.in. powołanie niezależnego od Kolegium Rzymskokatolickiego Greckokatolickiego Kolegium Duchownego i reorganizacja struktur diecezjalnych Kościoła. Ukazem z 22 kwietnia (4 maja - nowy styl) 1828 r. Mikołaj I poddał Greckounickie Kolegium Duchowne pod zwierzchnictwo metropolity Józefa Bułhaka ${ }^{11}$. Z czterech diecezji unickich utworzono dwa biskupstwa: białoruskie z siedzibą w Połocku i litewskie z rezydencją w monasterze w Żyrowicach. W przeciwieństwie do hierarchii Rosyjskiego Kościoła Prawosławnego Józef Siemaszko stopniowo wprowadzał zmiany w systemie zarządzania Kościołem, w obrzędach, tradycji i liturgii, np. zakaz wysyłania unitów do seminarium

\footnotetext{
9 I. Siemaszko, Zapiski..., s. 30.

10 W. F. Bacianowski, Iosif Siemaszko i wozsojedinienije unitow, „Istoriczeskij Wiestnik”, t. XIV, 1893 , s. 866.

11 E. Likowski, Dzieje Kościoła Unickiego..., cz. II, s. 59-60.
} 
katolickiego w Wilnie, utworzenie seminarium unickiego w Żyrowicach, oparcie szkolnictwa unickiego na systemie szkolnictwa prawosławnego, zrównanie prawne unitów z prawosławnymi w szkołach. Wprowadzone w latach 1828-1829 zmiany doprowadziły do odseparowania się hierarchii unickiej od katolickiej, zorganizowania własnego szkolnictwa i wzrostu nastrojów proprawosławnych wśród duchowieństwa i wiernych Cerkwi greckokatolickiej ${ }^{12}$.

Przeprowadzenie takich zmian wymagało przynajmniej neutralnej postawy biskupów unickich: wileńskiego i brzeskiego Jozafata Bułhaka, połockiego Jakuba Martuszewicza, łuckiego Cyryla Sierocińskiego oraz dwóch sufraganów: Adriana Hołownię, biskupa orszańskiego i Leona Jaworowskiego, biskupa włodzimierskiego. Biskupi ci nie cieszyli się zaufaniem władz rosyjskich, dwóch z nich - Hołownia i Sierociński zmarli w 1831 r., a Jaworowski i Martuszewicz w 1833 r. Jozafat Bułhak, który po Martuszewiczu objął arcybiskupstwo połockie, pozostał wierny unii. Pomimo to abp połocki podpisał wszystkie rozporządzenia, które przygotowywały likwidację obrządku greckokatolickiego. W 1829 r. Józef Siemaszko został sufraganem diecezji białoruskiej.

Józef Siemaszko, znając dzieje wprowadzenia unii, pragnął za wszelką cenę nie dopuścić do przemocy przy jej likwidacji. Zdawał sobie doskonale sprawę, że o postawie wiernych zadecydują ich duchowni. Pisał, więc: „Prosty lud stanie się prawosławnym tak szybko, jak szybko jego duchowieństwo stanie się prawosławnym" ${ }^{13}$. Ocena jego zyskała potwierdzenie w historii. Parafie unickie szybko stawały się prawosławnymi, gdy przeszli na „wiarę grecką” ich proboszczowie. Tam, gdzie księża opierali się przyjęciu prawosławia, dochodziło do wystąpień i protestów. Ażeby proces likwidacji unii przybrał charakter łagodny, szczególną rolę $\mathrm{w}$ nim przypisano szkołom unickim, a zwłaszcza seminarium w Połocku i Żyrowicach. Wychowywano tam duchownych w duchu teologicznej i kulturowej jedności z Cerkwią prawosławną.

Prace nad przygotowaniem synodu zjednoczeniowego zostały przyśpieszone wybuchem powstania listopadowego, które poparła część hierarchii unickiej i bazylianów. Na początku panowania Mikołaja I bazylianie posiadali trzy prowincje (litewską, białoruską i ruską) z 80 klasztorami męskimi i blisko 800 zakonnikami. Siemaszko wykorzystał udział duchownych unickich w powstaniu jako pretekst do rozwiązania wielu klasztorów bazyliańskich. W 1832 r. i w latach następnych rozwiązano ponad 50 klasztorów bazyliańskich a Ławrę Poczajowską przywrócono we władanie prawosławnych ${ }^{14}$.

Doceniając lojalną postawę biskupa Józefa, władze carskie wyraziły zgodę, po śmierci biskupa Jakuba Martusewicza w 1833 r., na wybór Siemaszki na

12 H. Dylągowa, Dzieje unii brzeskiej, Warszawa 1996, s. 83-84.

13 I. Siemaszko, Zapiski..., s. 30.

14 E. Likowski, Dzieje Kościoła Unickiego..., cz. II, s. 77; P. P. Gach, Kasaty zakonów na ziemiach dawnej Rzeczypospolitej i Śląska 1773-1914, Lublin 1984, s. 157, 161. 
ordynariusza diecezji litewskiej. Objęcie jej przez Siemaszkę praktycznie oznaczało rozpoczęcie aktu zjednoczenia unitów z Cerkwią prawosławną. Istotną przeszkodę na tym polu stanowiła polityka ordynariusza nowo utworzonego biskupstwa prawosławnego w Połocku. Biskup Smaragd - narodowości rosyjskiej - nie znał specyfiki prawosławia na Białorusi, a tym bardziej unii. Jego administracyjne metody likwidacji unii wywołały liczne protesty ze strony miejscowej ludności. Wprowadzenie wielkoruskiego prawosławia, niszczącego lokalną tradycję, niechętnie zostały odebrane w diecezji połockiej przez wiernych Kościoła prawosławnego i greckokatolickiego. Ponownie odradzały się prokatolickie sympatie wśród duchowieństwa unickiego. W tej sytuacji Siemaszko złożył wniosek o podporządkowanie Kolegium Greckokatolickiego Świętemu Synodowi, a po jego odrzuceniu, 12 maja 1833 r., złożył prośbę o przyjęcie unitów do Cerkwi prawosławnej. Jednocześnie biskup litewski przeprowadzał istotne reformy w Kościele greckokatolickim. Zlikwidował prawo patronatu i ktitorstwa, wprowadził do Kościoła unickiego prawosławne księgi liturgiczne. $\mathrm{W}$ cerkwiach ponownie wprowadzono ikonostasy, prawosławne utensylia i szaty liturgiczne.

W celu wprowadzenia powyższych zmian w Kościele unickim, Józef Siemaszko konsekrował w styczniu 1834 r. trzech biskupów pomocniczych: Bazylego Łużyńskiego, Jozafata Żarskiego i Antoniego Zubka. Sam biskup litewski przeprowadzał wizytację cerkwi unickich, badając stosunek duchowieństwa i wiernych do jego reform. Podczas wizytacji zbierał również podpisy duchownych pod aktem deklaracji przyłączenia do Cerkwi prawosławnej. Przeciwników zjednoczenia spotykały represje ze strony biskupa Józefa. Represje spowodowały usunięcie z parafii 130 dziekanów niechętnych reformom władyki litewskiego i zamknięcie ich w klasztorach ${ }^{15}$. Reakcją na działalność Siemaszki były protesty wiernych części parafii unickich, zwłaszcza na Białostocczyźnie, np. w 1838 r. w Kleszczelach.

Po powstaniu listopadowym car Mikołaj I odwołał konstytucję Królestwa i nadał mu Statut Organiczny w 1832 r. Pomimo że w sprawach wyznaniowych Statut Organiczny powtarzał postanowienia konstytucji, to całkowicie zmieniła się polityka władz carskich i Rosyjskiego Kościoła Prawosławnego wobec grekokatolików. Udział duchowieństwa katolickiego i unickiego w powstaniu 1830-1831 r. dał pretekst do wprowadzenia ograniczeń wobec wiernych tych dwóch odłamów Kościoła katolickiego. Polityka taka była realizowana przez namiestnika Królestwa Polskiego Iwana Paszkiewicza (1831-1856). Coraz więcej uwagi władze

15 A. Mironowicz, W zwiazku z 150 rocznica synodu połockiego (1839-1989), [w:] Chrześcijaństwo w Związu Radzieckim w dobie pierestrojki i głasnosti, pod red. W. Grzeszczaka i E. Śliwka, Pieniężno 1992, s. 142; M. Radwan, Carat wobec Kościoła greckokatolickiego w zaborze rosyjskim 1796-1839, Roma - Lublin 2001, s. 52-54. 
państwowe i cerkiewne poświęcały na pomoc ludności prawosławnej zamieszkującej zachodnie granice Imperium Rosyjskiego. Carat w celu zapewnienia sobie poparcia ludności rosyjskiej popierał ideologię państwa prawosławnego opartego na symbiozie: ,prawosławia, samowładztwa i narodowości rosyjskiej”. W odróżnieniu od poprzednika car Mikołaj I wspierał tendencje integrystyczne w Cerkwi prawosławnym ${ }^{16}$.

Wyrazem zmiany carskiej polityki wyznaniowej było nadanie licznych przywilejów Kościołowi prawosławnemu. Rada Administracyjna Królestwa 6 grudnia 1833 r. zwolniła duchowieństwo prawosławne z niektórych podatków z nieruchomości, które uznano „za wieczystą posiadłość Kościoła prawosławnego”. Ponadto zwiększano dotację państwową na budowę nowych cerkwi i na utrzymanie duchowieństwa. W dniu 20 sierpnia 1833 r. wprowadzono prawo o związkach mieszanych. Na jego podstawie dzieci narodzone $\mathrm{z}$ małżeństwa prawosławnych $\mathrm{z}$ innowiercami miały być ochrzczone i wychowane w wierze prawosławnej. Zmianę wyznania z prawosławnego na inną religię władze uznawały za przestępstwo ${ }^{17}$. Istotne przemiany nastąpiły w strukturze organizacyjnej Rosyjskiego Kościoła Prawosławnego na terenie dawnej Rzeczypospolitej. Na wniosek Świątobliwego Synodu doszło do ustanowienia drugiej katedry biskupa mińskiego w Grodnie i zmiany nazwy diecezji 30 kwietnia 1833 r. na mińsko-grodzieńską. O wiele większe konsekwencje przyniosło powołanie 22 kwietnia ( 3 maja - według nowego stylu) 1834 r. w diecezji wołyńskiej wikariatu warszawskiego. Mikołaj I w swym ukazie erekcyjnym stwierdził, że brak biskupa prawosławnego w Królestwie Polskim powoduje duże trudności w kontaktach duchownych i wiernych z własną hierarchią. Nowy biskup został wikariuszem diecezji wołyńskiej i uzyskał tytuł biskupa warszawskiego. Wkrótce miała zostać wybudowana dla niego rezydencja i konsystorz biskupi w Warszawie. Biskup warszawski miał podlegać Świątobliwemu Synodowi w Petersburgu i działać zgodnie z jego instrukcjami. Władykę zobowiązano również do zorganizowania seminarium duchownego dla kształcenia duchowieństwa prawosławnego ${ }^{18}$. Decyzją Świętego Synodu z 17 maja 1834 r. na biskupa warszawskiego powołano Antoniego Rafalskiego archimandrytę Ławry Poczajowskiej, która niedawno powróciła z unii do prawosławia. Cerkwią katedralną stała się jedyna prawosławna świątynia Św. Trójcy na Podwalu. Powyższe zmiany organizacyjne w strukturze cerkiewnej wskazują na wzrost zainteresowania caratu sprawami wyznaniowymi na terenach Królestwa Polskiego i zachodnich obszarach ziem białoruskich i litewskich. Na tamtym też obszarze zintensyfikowano działalność misyjną wśród unitów i katolików.

16 S. W. Rimskij, Stosunki między Cerkwiq prawosławna a państwem $w$ Rosji $w$ XIX wieku, [w:] Chrześcijaństwo $w$ dialogu kultur na ziemiach Rzeczypospolitej, pod red. St. Wilka, Lublin 2003, s. 402-411.

17 B. Kumor, Początki prawosławnego biskupstwa $w$ Warszawie, s. 283.

18 Ibidem, s. 283. 
Lata 1835-1839 były, podobnie jak w Kościele prawosławnym, okresem dynamicznych zmian w Kościele unickim. Przebudowano strukturę organizacyjną, wprowadzono prawosławne księgi liturgiczne, upodobniono wystrój wewnętrzny cerkwi unickich do prawosławnych. Mimo antyunickiej działalności biskupa połockiego Smaragda i wzmożonej agitacji kleru katolickiego następował również wzrost świadomości podjęcia aktu zjednoczeniowego wśród duchowieństwa greckokatolickiego. Fakt ten pozwolił Józefowi Siemaszce na ponowne zwrócenie się do Synodu Rosyjskiego Kościoła Prawosławnego pismem z 24 września 1836 r. o pozwolenie przejścia na prawosławie. Tym razem władze carskie zareagowały szybko. W styczniu 1837 r. został wydany ukaz carski o przekazaniu wszystkich spraw Cerkwi greckokatolickiej prokuratorowi Synodu. Równocześnie biskup litewski dokonał ponownej wizytacji parafii unickich diecezji litewskiej i białoruskiej, przygotowując duchowieństwo do przejścia na prawosławie. Siemaszko z satysfakcją stwierdził, że wszystkie cerkwie w jego władyctwie przypominają swym wystrojem wewnętrznym cerkwie przed 1596 r. Odmiennie wyglądała sytuacja w diecezji białoruskiej zarządzanej przez nieprzychylnie nastawionego do zjednoczenia metropolitę Jozafata Bułhaka. Dopiero jego śmierć w 1838 r. i zastąpienie go Bazylim Łużyńskim, zwolennikiem zjednoczenia, przygotowało władyctwo białoruskie do przyjęcia prawosławia ${ }^{19}$.

3 marca 1838 r. Józef Siemaszko został przewodniczącym Kolegium Greckokatolickiego. Z tego r. posiadamy szczegółowe dane o stosunku duchowieństwa unickiego do idei zjednoczenia. W diecezji litewskiej z 1857 duchownych za zjednoczeniem opowiedziało się 760, a w białoruskiej z 680 podpisy złożyło jedynie $186^{20}$. Antyprawosławne nastawienie duchowieństwa w diecezji białoruskiej było wynikiem działalności biskupa Smaragda. Ażeby zmienić tę sytuację, Siemaszko na początku 1839 r. udał się z biskupem brzeskim Antonim Zubko do Połocka, gdzie przeprowadził szeroką agitację za zjednoczeniem.

12 lutego 1839 r., w Niedzielę Prawosławia, zebrał się sobór, w którym wzięli udział: biskup litewski - Józef Siemaszko, połocki - Bazyli Łużyński i brzeski - Antoni Zubko, 24 wyższych duchownych oraz przedstawiciele społeczności świeckiej. Na soborze proklamowany został akt zjednoczenia, który został podpisany przez jego uczestników. Jednocześnie skierowano pismo do Synodu i cara Mikołaja I z prośbą o przyjęcie ich do Cerkwi prawosławnej. Do pisma dołączono wykaz 1305 osób duchownych, deklarujących się za ideą zjednoczenia. Zjednoczenia z prawosławiem nie poparło 593 duchownych unickich ${ }^{21}$.

19 M. Radwan, Carat wobec Kościoła greckokatolickiego w zaborze rosyjskim, s. 58.

20 A. Mironowicz, W zwiazku z 150 rocznica synodu połockiego (1839-1989), s. 143.

21 E. Likowski, Dzieje Kościoła unickiego na Litwie i Rusi w XVIII i XIX wieku, t. II, Warszawa 1906, s. 107-108; H. Dylągowa, Dzieje unii brzeskiej, s. 89-90. 
25 marca 1839 r. Synod Rosyjskiego Kościoła Prawosławnego wydał oświadczenie o następującej treści: biskupów, duchowieństwo $i$ wiernych do dziś greckounickiej Cerkwi zgodnie z prawami i przykładami ojców Cerkwi przyjmujemy do naszej wspólnoty prawosławno-katolickiej, wschodniej, wszechrosyjskiej Cerkwi. Greckokatolickie Kolegium Duchowne nazwano litewsko-białoruskim i podporządkowano Synodowi. Jego zwierzchnikiem został podniesiony do godności arcybiskupa Józef Siemaszko. W ten sposób oficjalnie nastąpiło zjednoczenie Kościoła greckokatolickiego z Cerkwią prawosławną na Białorusi i Litwie.

Pomimo że powrót unitów do prawosławia nie odbywał się dobrowolnie, to cała wieloletnia akcja likwidacji unii odbywał się bez rozgłosu i bez zewnętrznych wyrazów przymusu. Nic też dziwnego, że zaskoczony papież Grzegorz XVI nie podjął większych działań przeciwko Mikołajowi I. Papież pragnął utrzymać stan posiadania Kościoła łacińskiego w Cesarstwie Rosyjskim i otwarty konflikt $\mathrm{z}$ caratem nie był w interesie Rzymu ${ }^{22}$.

Postanowienia soboru połockiego powiększyły liczbę wiernych, duchowieństwa i parafii prawosławnych w zachodnich guberniach Imperium. Od 1839 r. prawosławie na ziemiach polskich i białoruskich zaczyna przyjmować coraz więcej cech prawosławia rosyjskiego (rozwój kultu świętych rosyjskich, obrzędowości, rosyjskiej architektury sakralnej). Władze carskie, ażeby skutecznie zarządzać zwiększającą liczbą parafii prawosławnych zmuszone były do dokonania reorganizacji struktury organizacyjnej Rosyjskiego Kościoła Prawosławnego. W 1839 r. diecezję mińsko-grodzieńską przemianowano na mińsko-bobrujską i nadano jej nowy kształt. 8 września 1839 r. ustanowiono wikariat biskupa mińskiego w Pińsku, zlikwidowany 28 stycznia r. następnego wraz nowymi zmianami organizacyjnymi. 1 października 1840 r. powołano do życia nowy wikariat na terenie diecezji wołyńsko-żytomierskiej, likwidując jednocześnie wikariat warszawski tegoż biskupstwa. Powyższe zmiany w istniejących diecezjach prawosławnych pozwoliły na powołanie dwóch nowych biskupstw. Po soborze połockim powstała w 1839 r. prawosławna diecezja litewsko-wileńska z wikariatem brzeskim (1839) i kowieńskim (1843). Wraz z diecezją litewską Świątobliwy Synod powołał dożycia biskustwo połockie z siedzibą w Witebsku (bp Bazyli) i w nowych granicach władyctwo mohylewskie (bp Izydor) ${ }^{23}$. Z części obszaru diecezji wołyńsko-żytomierskiej utworzono 5 października 1840 r. władyctwo warszawsko-nowogieorgiejewskie. Diecezja mińsko-grodzieńska zmieniła swoje granice i przyjęła w 1839 r. nazwę władyctwa mińsko-borujskiego.

22 A. Boudou, Stolica Święta a Rosja. Stosunki dyplomatyczne między niemi w XIX stuleciu, przekład z francuskiego Z. Skowrońska, t. I, Kraków 1928, s. 239-240, 250.

23 I. K. Smolicz, Istorija Russkoj Cerkwi 1700-1917, cz. II, Moskwa 1997, s. 344. 


\section{Liquidation of the church union during the Połock Council (1839)}

Due to the partition of the Polish Commonwealth five Uniat dioceses: metropolitan, Połock, Włodzimiersk, Łuck and Chełm - were included into the Russian Empire. The Russian Orthodox Church was malevolent towards Uniats. It was a common belief that Uniats should return to the Orthodox Church. The first action of conversion of Uniats was conducted in Wołyn and Podole in the years 1793-1794. As a result of the missionary action, supervised by bishop Wiktor Sadkowski, about 200 Uniat parishes, with about 1 million people, were converted to the Orthodox Church faith.

After the death of Catherine II the missionary action stopped. Tsar Paul II, although not very fond of Uniats, did not discriminate against them. During his reign, next to the already existing Połock archbishopric, Łuck and Brzesk bishoprics were restituted. In those days the Uniat Church had 1500 parishes, 80 Basilian monasteries and the faithful in the number of 1428000 . Alexander I did not fight against Uniats either. Nicholas I conducted a different policy towards them. He believed that Uniat clergy of Byelorussian or Ukrainian nationality belonged to the eastern cultural sphere, so he spared no efforts to include them into the Orthodox Church. During his reign state and church authorities increased their help offered to Orthodox people living in the west of the Russian Empire. The Uniat Church was to be devoid of Latin influences. Restoration of full eastern ceremony in Uniat churches was to be a preliminary stage of the peaceful unification with the Orthodox Church. Józef Siemaszko, remaining in the center of matters concerning Greek-Catholic ordinance, was to be the main protagonist of this process.

In 1827 Józef Siemaszko worked out a memorial on the state of the Greek-Catholic Church in Russia. In this document he analyzed the history of the union and presented a plan of the unification of the Uniat and Orthodox Churches. The project was supported by Nicholas I. The first significant movements aiming at the separation of Uniats from Catholics (e.g.: through establishing the Greek-Catholic College for Clergy, which was independent from the Roman Catholic College as well as through the reorganization of diocese structures of the Church) were undertaken in 1828. Changes introduced in the years 1828-1829 led to the separation of the Uniat and Catholic hierarchies, organization of the Uniat system of education and the strengthening of the pro-Orthodox mood among the clergy and the faithful of the Greek-Catholic Church. Works on the preparation of the unification synod were accelerated after the November Insurrection. Tsar Nicholas I totally changed his policy towards Greek-Catholics. Participation of Catholics and Uniats in the 1830-1831 insurrection gave him a pretext for the introduction of some restrictions imposed on the Uniat faithful. The years 1835-1839 were a period of numerous changes in the Uniat Church. The organizational structure was rebuilt, Orthodox liturgical books were intro- 
duced, Uniat churches' interiors were modeled after Orthodox churches' ones. Under the tsar's ukase of January 1837, all issues concerning the Uniat Church were to be handed over to the prosecutor of the Synod. On March 3, 1838 Józef Siemaszko started presiding over the Greek-Catholic College.

On February 12, 1839 Uniat bishops, 24 members of higher clergy and some lay representatives gathered at a council. They proclaimed and signed an act of unification. A list of 1305 members of clergy declaring their support for the idea of the unification was enclosed. The unification with the Orthodox Church was not supported by 593 members of the Uniat clergy.

On March 25, 1839 the Synod of the Russian Orthodox Church admitted Uniat clergy and lay people to its circle. The Greek-Catholic College for Clergy started to be called Lithuanian-Byelorussian College for Clergy and it came under the Synod's supervision. It was headed by Józef Siemaszko - promoted to the rank of Archbishop. In this way an official unification of the Greek-Catholic and Orthodox Churches took place in Byelorussia and Lithuania. 